Abstracta Iranica Abstracta Iranica

Revue bibliographique pour le domaine irano-aryen

Volume 27 | 2006

Comptes rendus des publications de 2004

\title{
Road Through Kurdistan: Travels in Northern Iraq. With introduction by David McDowall, London, New York, Tauris Parke Paperbacks, 232 p.
}

\section{Christine Allison}

\section{(2) OpenEdition}

1 Journals

Édition électronique

URL : http://journals.openedition.org/abstractairanica/6079

DOI : 10.4000/abstractairanica.6079

ISSN : 1961-960X

Éditeur :

CNRS (UMR 7528 Mondes iraniens et indiens), Éditions de l'IFRI

\section{Édition imprimée}

Date de publication : 15 mai 2006

ISSN : 0240-8910

\section{Référence électronique}

Christine Allison, «Road Through Kurdistan: Travels in Northern Iraq. With introduction by David McDowall, London, New York, Tauris Parke Paperbacks, 232 p. », Abstracta Iranica [En ligne], Volume 27 | 2006, document 226, mis en ligne le 02 janvier 2007, consulté le 25 septembre 2020. URL : http:// journals.openedition.org/abstractairanica/6079; DOI : https://doi.org/10.4000/abstractairanica.6079

Ce document a été généré automatiquement le 25 septembre 2020.

Tous droits réservés 


\title{
Road Through Kurdistan: Travels in Northern Iraq. With introduction by David McDowall, London, New York, Tauris Parke Paperbacks, 232 p.
}

\author{
Christine Allison
}

1 A welcome re-edition in affordable format of one of the classic autobiographical accounts of the British Mandate, this amiable book (which was first published in 1937) describes Hamilton's experiences as engineer in charge of a new road from Erbil to Persia through the gorges and mountains of Kurdistan, along ways previously only passable by mule. It took a workforce of six hundred men of various nationalities and religions, equipped with explosives and machinery, four years to complete; local Kurds still refer to the road as the 'Hamilton highway'.

2 Hamilton describes not only the building of the road, winding over passes and blasting through gorges, but also the surveys (whose dangers lay not only in the precipitous terrain but also in the uncertain loyalties of local tribes). He describes leisure activities such as hunting for ibex as guests of Kurdish chiefs, and for treasure in great mountain caverns. The account is distinguished by personal modesty, a sense of humour and a respect for the endurance, courage and generosity of mountain Kurds and Assyrians.

3 David McDowall's useful introduction adds some information on the life and background of Hamilton himself, on the identities of some of the other British officers who feature in the book (some pseudonyms are further clarified in the index), and highlights some inaccuracies, but for the most part lets Hamilton speak for himself. 
INDEX

Thèmes : 4.5. Histoire des kurdes

\section{AUTEURS}

CHRISTINE ALLISON

Mondes iranien et indien - INaLCO 